\title{
Risk of Disability, Old-age and Death: Pension Sustainability in Colombia
}

\author{
Sergio Clavijo ${ }^{1}$, Alejandro Vera ${ }^{1}$, David Malagón ${ }^{1}$, Laura Clavijo ${ }^{1}$, Andrea Ríos $^{1}$, Ekaterina Cuéllar ${ }^{1} \&$ Nelson \\ Vera $^{1}$ \\ ${ }^{1}$ Asociación Nacional de Instituciones Financieras ANIF, Bogotá, Colombia \\ Correspondence: Laura Clavijo, Asociación Nacional de Instituciones Financieras ANIF, Bogotá, Colombia. Tel: \\ 57-1-312-4525. E-mail: lclavijo@anif.com.co
}

Received: November 9, 2016

Accepted: February 23, 2017 Online Published: February 28, 2017

doi:10.5539/jms.v7n1p103

URL: http://doi.org/10.5539/jms.v7n1p103

\begin{abstract}
This paper concludes that the sustainability of the public "pay-as-you-go" pension regime in Colombia (RPM) looks fragile and is threatened by massive transfers from the private "defined contributions" regime (RAIS) to the RPM. The fiscal deficit of the RPM could be rising from 140\% of GDP (in NPV) to $228 \%$ of GDP during the next three decades on account of the migration of close to nine million retirees moving to the RPM. Pressure to the fiscal budget will increase towards $90 \%$ of GDP (in NPV) as a result of the pension shortfall, making it very difficult to comply with a fiscal target of $4 \%$ of GDP per year. In addition, the life annuities' market is quite shallow in Colombia due to: i) the State guarantee of a pension equivalent to $100 \%$ of a legal-minimum-wage (1 LMW); which in turn is fully indexed to annual inflation; and ii) the risk of assuming longer periods of pension enjoyment via judicial sentences (elevating the current expectations of 20-25 year period of enjoyment). Limiting the pension guarantee to $50-75 \%$ of a LMW, allowing for life-annuities recalculation, and decreasing the cost-margin of insurance companies would help place the Colombian life annuities market in a more financially sustainable path.
\end{abstract}

Keywords: social security, public pensions, private pension schemes

\section{Introduction}

The period 2014-2015 has been characterized by macro-financial tension, especially for emerging economies (EM). Several factors have contributed to this phenomenon, and have led to a potentially lower annual growth rate for EMs in the $4 \%-4.5 \%$ range, below the $6 \%$ growth rate in the era pre-Lehman (see BIS 2015). Some of the factors that have contributed to this are the following: i) the end of the commodities "super-cycle" for metal exporters (with price contractions of $-40 \%$ after peaking in 2011) as well as oil exporters (-50\% since 2014 ), situation that has been exacerbated by China's economic slowdown; ii) the strong devaluation of EM currencies, averaging 25\%-35\% per year during 2015, accompanied by pass-through effect, inflation and interest rate hikes; and iii) a pronounced increase in the external debt (public and private) of EMs, with a resulting risk of exchange-rate mismatch.

This panorama has been particularly dire for Colombia. The decreasing price of oil has had negative effects, mainly: i) intensifying the twin deficits, reaching $6 \%$ of GDP in the current account (vs. $4.3 \%$ historically) and a $3 \%-4 \%$ of GDP fiscal deficit (vs. $2.4 \%$ for 2013-2014); ii) $35 \%$ depreciation against the dollar during 2015 , resulting in higher inflation due to exchange rate pass-through effect $(+5.8 \%$ end-2015), requiring the Central Bank (BR) to increase its interest rate to $5.25 \%$ at the end of 2015 (vs. $4.5 \%$ in 2014); and iii) losses worth $0.5 \%$ of potential economic growth (leading a historical $4.5 \%$ growth rate to fall towards the $3.5 \%-4 \%$ range), due to the inability to reactivate key sectors such as agriculture and the manufacturing industry.

These events have exposed structural weaknesses of the Colombian economy, unveiling the consequences of having missed the opportunity that the 2004-2014 boom represented in terms of advancing with structural reforms. This is particularly true in terms of fiscal adjustments, infrastructure-competitiveness and pension-labor reforms. This paper addresses many of the pension challenges to be faced, with special attention to the pension accumulation cycle as well as the de-accumulation phase.

Multilateral agencies (World Bank and IADB), as well as the OECD have stressed the urgent need for a structural pension reform in Colombia, in line with what Anif and Fedesarrollo have been claiming for quite 
some time: Colpensiones' public sector pay-as-you-go scheme regime (RPM, Régimen de Prima Media) is unjust and has been generating increasing pressure on the public budget. In particular, the OECD has recommended withering the RPM, claiming that, even worldwide, there are serious challenges in adjusting this scheme to drastic demographic changes (Anif, 2015).

In contrast, the advantages of the private sector, a defined contributions regime (RAIS, Régimen de Ahorro Individual) lies in that it doesn't generate fiscal shortfalls, because future pension allowances will match the bulk of contributions and the return on the portfolio, operating under the "magic" spell of compounded interest. Only in the case in which the government must guarantee a minimum pension the system may need to complement resources with additional budgetary contributions.

Let's bring to mind that in Colombia, in order to gain access to a pension under the pay-as-you go RPM, the following requirements must be met (according to Law 797 of 2003): i) having contributed for 1300 weeks (25 years); ii) age of retirement of 57/62 years (men/women). On the other hand, under the RAIS, retirement conditions are given by the contribution amount that each worker has accumulated, where the minimum amount equals one Legal Minimum Wage (LMW).

In the event that the age requirement is met (under the RPM), but not the minimum time of contribution ( 25 years), savings will be reimbursed and adjusted only by inflation. In case the minimum savings amount is not reached (under the RAIS), these savings will be returned not only adjusted by inflation, but in addition by a return on market real interest rate.

Given the current low density of pension contributions, it is estimated that $80 \%$ of active contributors (close to 7.4 million Colombians) will fall short of reaching a pension, which implies that for the majority of contributors the private sector RAIS scheme (under which savings yield a real return) is more convenient than the public sector RPM (under which only inflation is recognized). Notice that if the difference between the reimbursements based on real return vs. inflation were equal to $3 \%$ per year in real terms, then the values recognized by the RAIS would surpass those for the RPM in an amount of $40 \%$ during two decades or equivalent to $70 \%$ in three decades.

Consequently, the $20 \%$ that are entitled to receive a pension will encounter the following options. Under the RPM, they will receive a life-long pension, whose value will depend on the accumulated time of contribution, which in turn will depend on the "replacement rate" (pension allowance/average wage). This replacement rate (RR) will fluctuate between $65 \%$ and $75 \%$ for the vast majority of retirees, following recent adjustments to Law 797 of 2003 (whereas, the global regime hovers around the 45\%-50\% range). The exception being the case of a minimum pension, which in Colombia equals $100 \%$ of the LMW by constitutional mandate, compared to a $75 \%$ of LMW in Chile.

Under the public sector regime, the State must assume the actuary risk of "extra-longevity" of retirees (resulting from higher life expectancy beyond the 57/62 years of age for women/men, which applied since 2014), in addition to the legal risk of pension augmentation because of "surviving beneficiaries".

In contrast, under the RAIS there are two alternatives: i) commission a pension fund (AFP) to manage savings under the "programmed retirement" scheme, where the pension allowance will vary according to portfolio performance and the retiree-s expected longevity (nevertheless, the Supreme Court has ruled that these schemes must yield at least the inflation rate, which shows that they have failed to understand the whole point of this scheme); or ii) acquire a "life annuity" with an insurance company, situation for which the insurer must carefully evaluate the trade-off between expected allowance and life-expectancy, return and duration of assets available for investment, as well as the legal risk of pension augmentation because of "surviving beneficiaries" (Anif, 2014).

In Colombia, the real problem is the fact that pension benefits are generous (LMW pension, $100 \%$ allowance in the case of a deceased retiree, etc.), and must be financed using savings that are insufficient. This is the result of characteristics particular to the contributions system (low income, irregular contribution, evasion and elusion, etc.). In consequence, both the market for programmed retirement as well as for life annuities exhibit low levels of penetration. Currently, the RAIS holds close to 81,000 retirees (5\% of total), of which only 21,000 are retired because of old age.

Furthermore, there is evidence showing that there is little depth in the life annuities market. This segment accounts for just $13 \%$ of old-age retirees (vs. 66\% in Chile) even after 20 years of the RAIS, whereas programmed retirement takes up the remaining $87 \%$ (vs. 34\% in Chile), Anif 2015.

This raises many concerns regarding the financial sustainability of the RAIS. On one hand, there is evidence that 
shows that life annuities are not targeting low-income retirees (close to 70\%), which are also the segment of the population that needs coverage to prevent a situation in which savings are insufficient to meet the $1 \mathrm{LMW}$ requirement. On the other hand, even for high-income cases, there is a higher concentration risk for pension funds, who must simultaneously manage core business risks (operational, minimum return, etc.) as well as the risk of savings shortfall (longevity, financial and legal), while optimizing portfolios and recalculating allowances (which must readjust to recognize inflation according to the aforementioned Constitutional Court (CC) ruling).

To this date, the lackluster performance of the life annuities scheme in Colombia is mainly due to the "risk of a sliding LMW". This risk results from the fact that close to $70 \%$ of pensions are close to the LMW and must be adjusted to inflation (by constitutional mandate). Furthermore, the annual adjustment of the LMW has experienced a "political" premium by which the "universal rule" has been surpassed, whereby Var. \% LMW > inflation +/- Var. \% labor productivity. On average, 1 LMW retirees have benefited from a "premium" worth $0.4 \%$ per year during the last decade, leading to an extra cost for insurance companies.

More recently, the government has been moving in the right direction by establishing coverage mechanisms that will enable insurance companies to cover this risk of a sliding LMW, as captured by Decree 36 of 2015. This decree states that the government should assume the shortfall in pension resources resulting from LMW adjustments that exceed inflation plus gains in labor productivity (taking into account the past 10-year average). In contrast, when reserves exceed the actuary value of future obligations, insurance companies should pay the government the mathematical reserve surplus.

In terms of the pension shortfall that the RAIS must entail, drafted regulation sets new capital requirements specific to programmed retirement. Capital must be sufficient to ensure the issuance of a life annuity in the same amount. In addition, a margin is being introduced by which a life annuity will be mandatory, equivalent to 1.1 of the amount required for a 1 LMW pension.

Even though these regulatory developments should help promote life annuities, there is still much work to be done in terms of adjusting the group of substitute beneficiaries, as has been pointed out by Fasecolda (the Colombian Insurance Lobby's Organization). This group definition was enlarged by Law 797 of 2003, and now includes disabled siblings (that area economically dependent to the retiree) and permanent companions (not oust spouses) as beneficiaries of the surviving pension. This last point is particular damaging because, by allowing simultaneous beneficiaries (previous spouse and current companion), the actuary calculation takes into account two lives-span. Furthermore, the CC has made the burden on beneficiaries more taxing: i) Sentence C-1176 of 2001 declared the requirement of "recognizing marital status from the moment in which requirements to obtain pension right" as unconstitutional; ii) Sentence C-111 of 2006, which states that parents may be beneficiaries in the case where the retiree's income is relevant to them; and iii) Sentence C-336 of 2008, which recognizes a surviving pension of same-sex couples.

The idea is that the sum of all these factors should be "predictable" when calculating pension insurance under a life annuity scheme. This would allow insurance companies to recalculate pension allowances and make them financially viable, as is the case in Chile (Anif, 2014). In this way, the challenge in Colombia is that of making the RAIS scheme sustainable during the de-accumulation phase by a recalculation of pension allowance. This requires addressing the thorny judicial issue of unexpected past beneficiaries appearing in life annuity contracts (with a further complication: the impossibility of reducing a life annuity beyond $1 \mathrm{LMW}$ ).

Another issue is the fact that the pension system not only covers through insurance policies the risk of old-age, but also that of disability and survival. These risks are transferred by each pension fund to an insurance company in exchange for a premium, which must be calculated as a fraction of an overall $3 \%$ contribution fee (the remaining portion is the fee that the pension fund receives).

\section{Method}

This paper addresses these pension system challenges, both for the accumulation and de-accumulation stages. The first set of estimations aim at determining the Net Present Value (NPV) of the pension system, from the RAIS-RPM migration phenomenon, which has been spurred by the "unfair" competition that Law 100 de 1993 enabled by facing RAIS private-savings to RPM government subsidies. The second set of results reviews the de-accumulation of pension savings under the scope of life annuities. In particular, we will focus on pension shortfall and the value of life annuity premium, which helps explain the lack of depth within the life annuity market in Colombia.

\subsection{Pension Migration Model (from RAIS to RPM)}

The risk of fiscal unsustainability for the public sector pay-as-you-go regime (RPM) are becoming clearer with 
every passing day due to: i) a parametric misalignment resulting from assuming a lower age of retirement of $57 / 62$ (women/men) compared to the 65 -year international standard, and a high replacement rate of $65 \%-75 \%$, even though market benchmarks fall within the 45\%-50\% range; and ii) unfair competition between the RAIS-RPM which has resulted in massive transfers towards the RPM, driven by government subsidies.

In fact, these transfers have increased significantly during the last five years, averaging 185,000 per year (vs. marginal figures prior to 2005). This implies that close to 1 million contributors have been expanding the RPM and therefore deepening the fiscal deficit (see Figure 1). Notice how these transfers peaked at 480,000 in 2009 due to Decree 3995 of 2008 that revised the contributor base and eliminated the phenomenon of simultaneous affiliation.

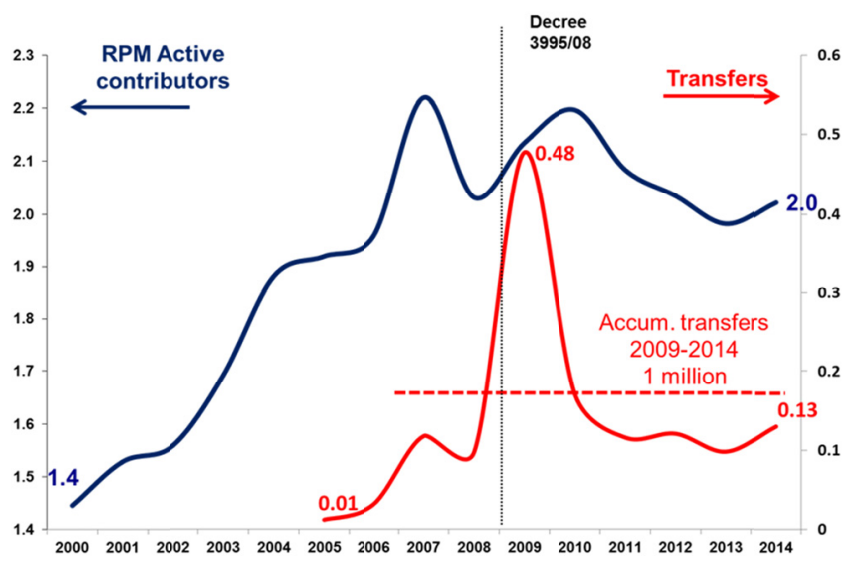

Figure 1. RPM active contributors and RAIS-RPM transfers (million)

Source: Anif estimations based on Superfinanciera.

In the first section of this chapter, we will model the future course of RAIS-RPM transfers, as a function of interest rate dynamics. To this end, we will construct a semi-elasticity model between current RAIS contributors and the expected return on their portfolio. It is here that lower expected returns would entice retirees to migrate to the public-subsidized regime in seeking higher replacement rates. On the contrary, higher interest rates would attract contributors to remain with the RAIS, and allow compounded interest to do its "magic".

In the second section, we will calculate the pension NPV that would support these transfers by plugging them into the wage distribution of social security (PILA) contributors. This estimation includes the effect of updated mortality tables that gives evidence of increasing fiscal pressure due to higher longevity of the Colombian population for the 2015-2050 horizon.

As was mentioned previously, the key element to our model consists of estimating semi-elasticities of active RAIS-RPM contributors against historical pension fund returns. By calculating these parameters, we find a $+5.5 \%$ semi-elasticity between current RAIS contributors and interest rates, see Table 1 . This estimation captures just how attractive the RAIS is in presence of higher returns. On the other hand, we find a $-4.3 \%$ semi-elasticity for RPM contributors. This is consistent with the fact that there are greater incentives to migrate from RAIS to RPM when facing lower returns. We will be analyzing three scenarios in terms of possible long-run interest rates. 
Table 1. Macro and demographic assumptions (base scenario)

\begin{tabular}{ll}
\hline & Assumption \\
\hline Inflation & $3.0 \%$ \\
Labor productivity & $1.0 \%$ \\
Discount rate & $6.0 \%$ \\
Real return on portfolio (avg. 2015-2050) & $7.0 \%$ \\
Semi-elasticity active contributors to return (10 yrs) & $5.5 \%$ \\
RAIS (1pp) & $5.5 \%$ \\
RPM (1pp) & $-4.3 \%$ \\
Years of contribu6ion & 25 \\
Replacement rate (Law 979 of 2003) & \\
1 LMW & $100 \%$ \\
2 LMW & $65 \%$ \\
5 LMW & $63 \%$ \\
10 LMW & $61 \%$ \\
Years of pension enjoyment & 25 \\
\hline
\end{tabular}

Source: Anif.

\subsection{Life Annuity Premium Model}

In the previous chapter, we addressed the pension problem resulting from RAIS-RPM migration. In this section, we model the depletion of RAIS savings (given that we have already explained how RPM payments must be covered by the PGN). In particular, we will focus on the life annuities market and the gap between contributor savings and the cost of life annuity premiums.

Previously, we mentioned that this shortfall results from the lack of depth within the life annuities market in Colombia. As a matter of fact, this scheme concentrates just $13 \%$ of old-age retirees from the RAIS (compared to $66 \%$ in Chile, after 20 years since this private sector regime has been operating).

In particular, we highlight the problems resulting from: i) the legal contingency that prevents the renegotiation of life annuity contracts when facing the appearance of new beneficiaries (despite the fact that the Law allows for renegotiations; and ii) the elevated cost of issuing life annuities that support the minimum 1-LMW pension. At least on this front, there has been some regulatory steps contained in Decree 36 of 2015 that should help ease this affliction. With this, the government would begin to assume the additional cost of "populist" increases of the LMW beyond labor productivity gains (estimated at $0.92 \%$ according to recent data).

To estimate the value of the premium that an insurance company should charge on a life annuity, we employ a cash-flow model as illustrated by Figure 2. This estimation assumes that the key parameter is the amount of time of enjoyment of the annuity, considering potential beneficiaries as well as legal contingencies (this is the main difficulty that insurance companies face). To accomplish this, we calculate the expected value of enjoyment, taking into account the probability of duration of the annuity (retiree + beneficiary). Notice how we have captured these legal contingencies by lengthening the duration of the annuity. By taking into account the probability of duration, we are able to estimate the expected value of enjoyment close to 25 years.

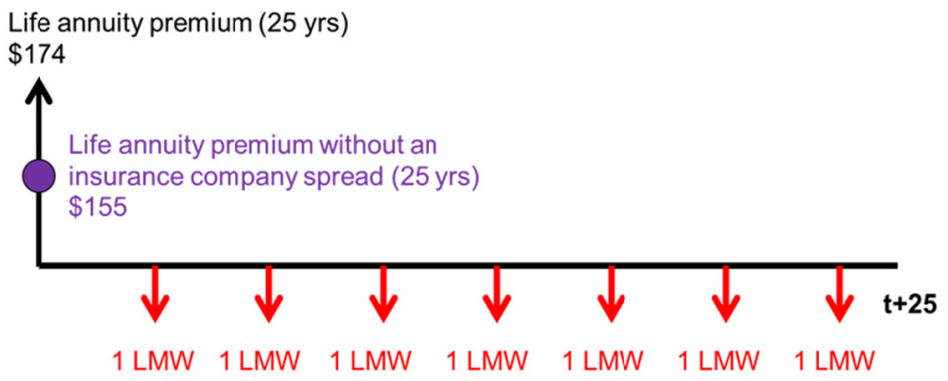

Figure 2. RPM active contributors and RAIS-RPM transfers (million)

In addition, other key parameters are the following: i) the return on the investment portfolio (return on premiums), for which we will fix the historical return on treasury securities TES ( $4 \%$ real); ii) the indexation of 
the pension allowance, considering the inflation rate (3\% long-run Central Bank target) for allowances above 1 LMW, and an additional labor productivity margin $(0.92 \%)$ for the case of 1 LMW; and iii) the spread that insurance companies will charge, which we assume to be $1 \%$ of AUM, see Table 2.

Table 2. Assumptions: life annuity premium estimation

\begin{tabular}{ll}
\hline & Assumption \\
\hline Inflation & $3.0 \%$ \\
Labor productivity & $0.92 \%$ \\
Real return securities TES & $4.0 \%$ \\
Real return pension portfolio & $7.2 \%$ \\
Insurance company spread & $1.0 \%$ \\
\hline
\end{tabular}

\section{Results}

\subsection{Pension NPV Resulting from RAIS-RPM Migration}

\section{Base Scenario}

The base scenario assumes the following parameters: i) long-run annual inflation of 3\% (despite the fact that this target will be missed in 2015-2016 due to higher exchange rate pass-though and higher food prices driven by the climatic effect); ii) labor productivity of $0.92 \%$ for LMW indexation purposes, in line with Decree 36 de 2015 ; iii) average real return on pension funds of $7.2 \%$ per year (below a historical average of $8.4 \%$ ); iv) 25 years of contributions (1.300 weeks) and a replacement rate within the range $61 \%-100 \%$, as given by Law 797 of 2003 ; and v) 25 years of enjoyment (widows), consistent with an increase in life expectancy (hovering close to 75 years of age).

Figure 3 shows the expected path of interest rates for the period 2015-2050. Here we see that returns would be decreasing from a historical average of $8.4 \%$ per year in real terms towards $6 \%$ in 2050 , and averaging $7.2 \%$ for the period of analysis. The macro-financial outlook explains the declining trajectory in interest rates, mainly: i) what professor Summers has called "secular stagnation", where lower growth potential for developed economies is requiring lower "natural" interest rates; and ii) the end of the commodities super-cycle, with a particular effect on pension fund investments in emerging markets (Colombia included). Notice how some of the more important pension funds worldwide (CalPERS-Caltech) have considered reducing their discount rates to 5\% (vs. 7.5\%-8\% currently) because of lower expected returns, which would imply an increase in pension liabilities (Center for Retirement Research, 2015).

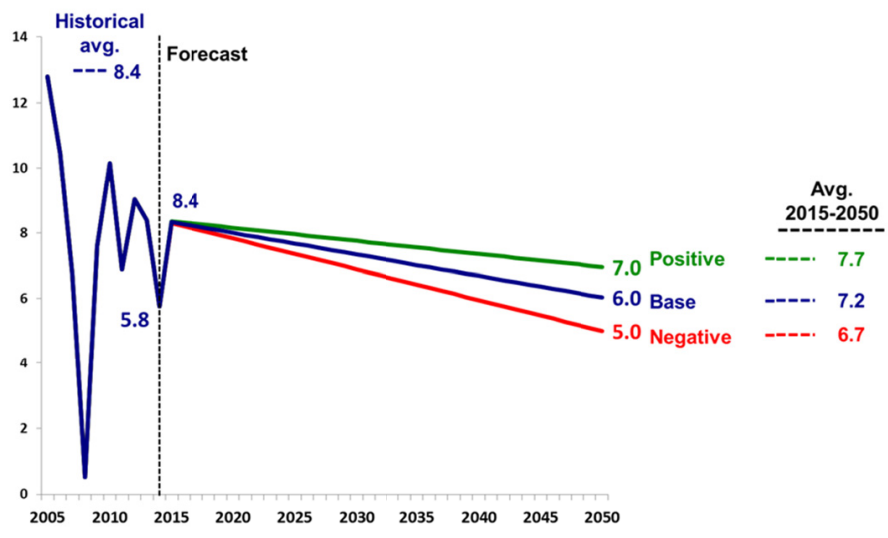

Figure 3. Average real return on pension funds (\%)

This interest rate path would result in greater RAIS-RPM transfers, going from 130.000 in 2014 to 274.000 in 2050 (for a total of close to 9 million transfers for the 2015-2020 horizon), see Figure 4. This, in addition to demographic dynamics, would imply that the total number of active contributors RAIS+RPM would increase from 9 million in 2014 to 21 million in 2050 (for all three scenarios). Therefore, the composition of active contributors RAIS/RPM would change slightly from $77 \% / 23 \%$ at the end of 2014 (7 million in RAIS / 2 million in RPM) to $72 \% / 28 \%$ by 2050 (15/6 million), see Figure 5 and 6 . Notice that close to half of RPM's active 
contributors in 2050 would result from transfers occurring over the course of the forecasted horizon, see Figure 7.

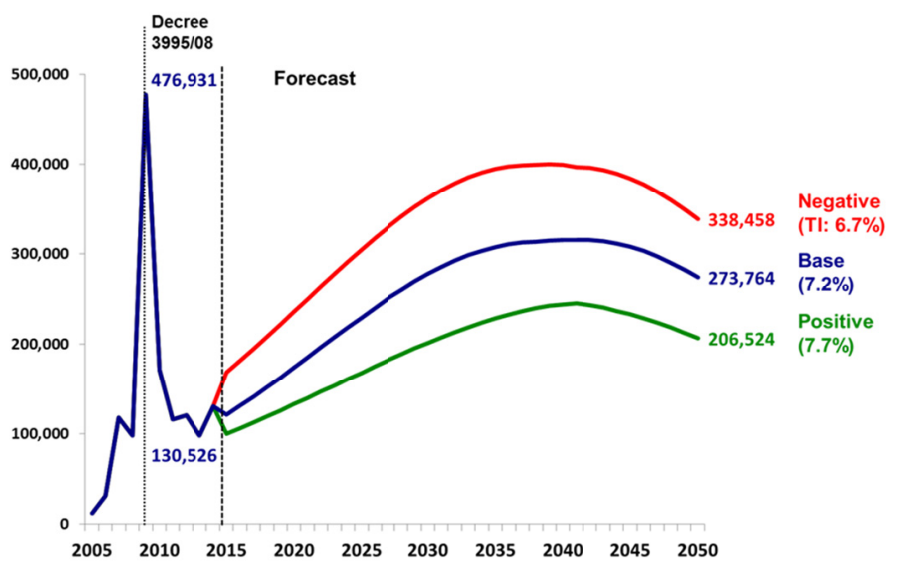

Figure 4. RAIS-RPM transfers (number of people)

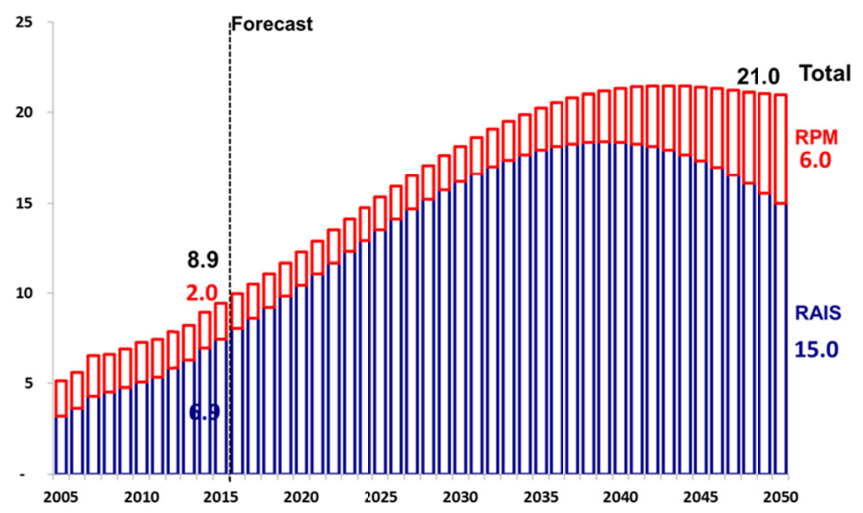

Figure 5. RAIS vs. RPM active contributors, base scenario (million people)

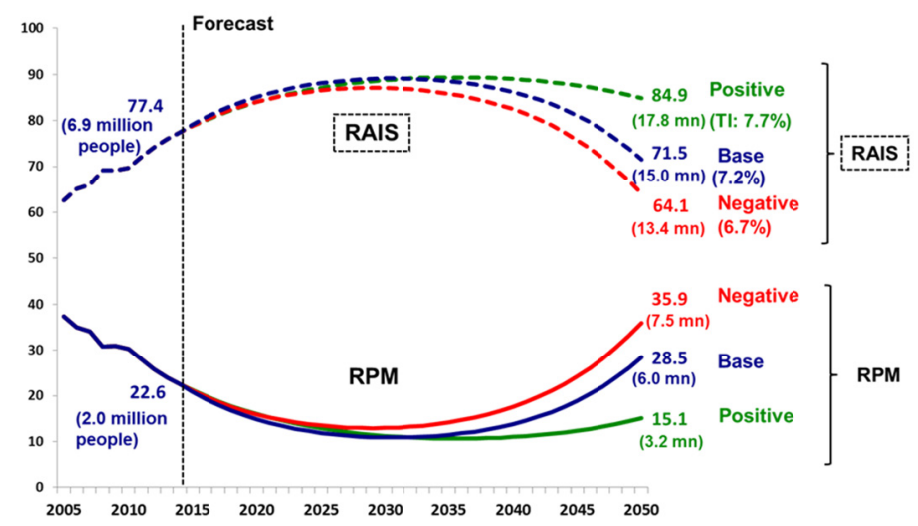

Figure 6. Share of active contributors, RAIS vs. RPM (\%) 


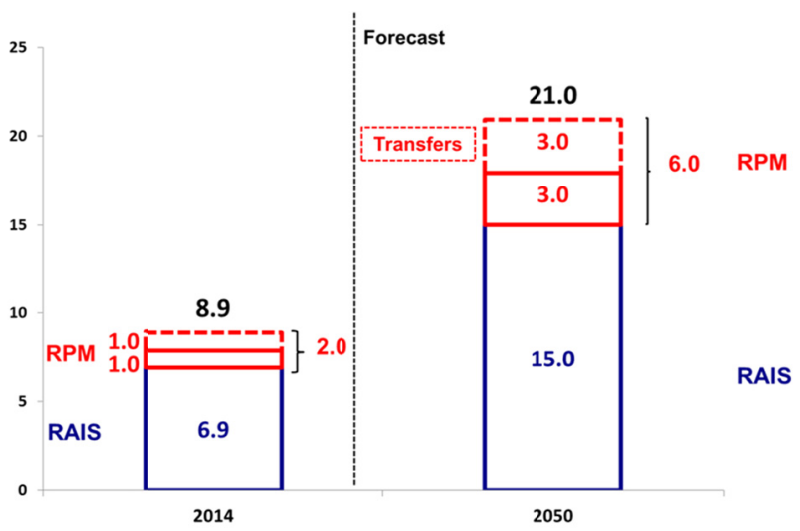

Figure 7. Active contributors, RAIS vs. RPM, base scenario (million people)

These estimations are consistent with significant gains in labor formalization, understood from the point of view of active social security contributors (PILA) to the economically active population (PEA). This relationship would increase from $40 \%$ to $56 \%$ in 2050 (for all three scenarios), see Figure 8 . In these calculations, we are taking into account: i) demographic trends resulting in growth of population and PEA $(+1.2 \%$ per year); and ii) gains resulting from the elimination of Cofamiliares, enhancing the outcome under Law 1607 of 2012 (13.5bps = $2 \%$ Sena $+3 \%$ ICBF $+8.5 \%$ Health), see Clavijo et.al. 2015. Notice how despite these gains in formalization, we are still far from reaching levels of 70-90\% reported for Chile and Spain.

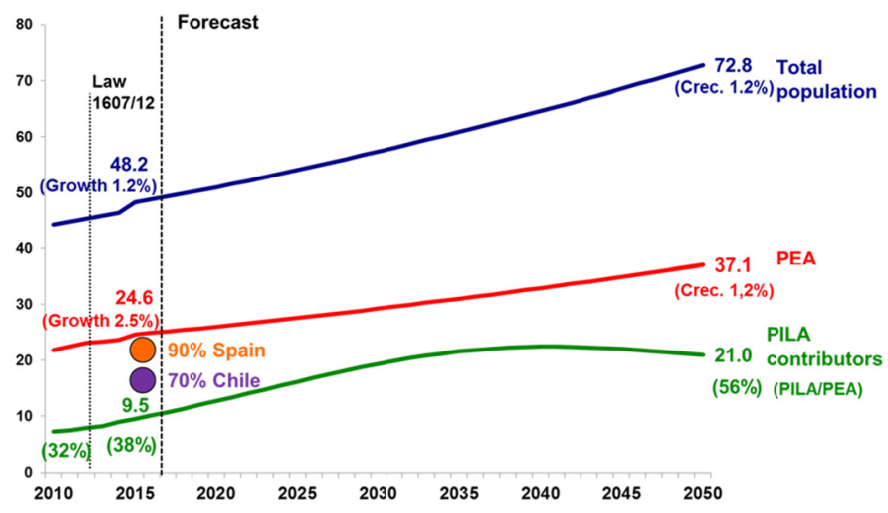

Figure 8. Labor formality check (million people)

\section{Positive Scenario}

Under the positive scenario, pension fund interest rates would reach an average of $7.7 \%$ per year for the period $2015-2050$ ( $+0.5 \%$ against base scenario). This scenario assumes a milder effect from secular stagnation and a slight rebound of emerging economies when compared to the base scenario. In addition, we have included a longer period of contribution of 30 years ( +5 years from the base scenario), in line with higher life expectancy, which in turn would reduce some of the financial pressure to the system.

This interest rate trajectory would result in greater transfers RAIS-RPM, going from 130.000 in 2014 to 207.000 in 2050 (for a total of close to 7 million transfers for the 2015-2020 horizon; -2 million with respect to the base case), see Figure 4. Therefore, the composition of active contributors RAIS/RPM would change slightly from $77 \% / 23 \%$ at the end of 2014 to $85 \% / 15 \%$ by $2050(+13 \% /-13 \%$ against the base scenario), see Figure 5 and 6 .

\section{Negative Scenario}

Under this stressed scenario, pension fund interest rates would decrease to an average of $6.7 \%$ per year for the period 2015-2050 (-0.5\% against base scenario). In addition, this scenario assumes harsher conditions in terms of longer periods of pension enjoyment of 30 years (widow), which in turn increases the probability of legal contingencies (greater number of beneficiaries). 
This scenario would lead to greater RAIS-RPM transfers, going from 130.000 in 2014 to 338.000 in 2050 (for a total of close to 12 million transfers for the 2015-2020 horizon; +3 million with respect to the base case), see Figure 4. Therefore, the composition of active contributors RAIS/RPM would change slightly from $77 \% / 23 \%$ at the end of 2014 to $64 \% / 36 \%$ by 2050 (-8\%/+8\% against the base scenario), see Figure 5 and 6 .

To these estimations, we must now add the pension-NPV resulting from additional transfers derived from our semi-elasticity interest rate model. To this respect, we will plug different transfer scenarios into the wage distribution of active contributors in Colombia. We will assume four types of representative agents according to wage range: agent A (contributing on $1 \mathrm{LMW}$, represents $58 \%$ of PILA-contributors), agent B (2 LMW, $24 \%$ of PILA- contributors), agent C (5 LMW, 14\%) and agent D (10 LMW, 4\%).

Base Scenario (25 years of contribution and enjoyment; real return of $7.2 \%$ )

Actuary results for the base case are analyzed by looking at following variables: i) total savings or accumulated pension contributions that each worker pays throughout his/her work lifespan; ii) NPV of the subsidy or the difference between the "actual value" of pension payments offered by RPM and potential payouts that workers could receive by cashing-out savings under the market model (RAIS); iii) NPV of the pension or the "actual value" of pension payouts received under RPM; iv) the replacement rate or Benefits/Contributions ratio; and v) replacement rate or benefits/contribution ratio. We have used as a starting point pension contributions equivalent to $11.5 \%$ of monthly wage, with $100 \%$ density and calculated immediately prior to time of retirement.

Using 2015 prices, agent A earning $1 \mathrm{LMW}$, manages to save close to $\$ 32$ million during the working lifespan, assuming a $7.2 \%$ annual real return rate on contributions balance. Nevertheless, he receives a pension (in NPV, with a $6 \%$ discount rate) of $\$ 102$ million because his minimum pension must be at least equivalent to $1 \mathrm{LMW}$. Therefore, the NPV of the subsidy should be close to $\$ 70$ million (pesos of 2015), equivalent to $69 \%$ in terms of the subsidy/pension ratio, see Table 3 .

Table 3. Per-capita pension subsidy, base scenario (NPV \$ million of 2015)

\begin{tabular}{lllll}
\hline Agent type & Total Savings & Subsidy & Pension & Subsidy / Pension \\
\hline A (1 LMW) & 31.9 & 69.7 & 101.6 & $69 \%$ \\
B (2 LMW) & 63.9 & 49.6 & 113.5 & $44 \%$ \\
C (5 LMW) & 159.7 & 117.5 & 277.1 & $42 \%$ \\
D (10 LMW) & 319.3 & 213.0 & 523.3 & $40 \%$ \\
\hline
\end{tabular}

Note. Assuming each agent contributes for 25 years and enjoys pension for 25 years.

Similarly, individual B could save more than agent A, given the fact that he earns a higher wage (2 LMW). In this case, the pension offered by the government is calculated against $65 \%$ of his 10 -year average wage, according to the replacement rate formula given by Law 797 of 2003 (detailed previously). Therefore, this individual manages to save close to $\$ 64$ million (pesos of 2015) during his working lifespan. Nevertheless, because he receives a pension worth $\$ 114$ million he receives a 44\% subsidy. Agent C (5 LMW) manages to save close to $\$ 160$ million and receives a pension worth $\$ 277$ million (a $\$ 118$ million subsidy; $42 \%$ of his pension). Finally, agent D (10 LMW) receives a $\$ 213$ million subsidy ( $40 \%$ of his pension).

Notice how these implicit subsidies tend to be less (in relative terms) for higher wages, and are highly regressive in absolute terms. For example, agent D (10 LMW) will receive a subsidy worth $\$ 213$ million, three times as much the $\$ 70$ million perceived by agent $\mathrm{A}$ (contributing with $1 \mathrm{LMW}$ ).

In terms of the replacement rate, agent A ( 1 LMW) will receive a pension worth $100 \%$ of his salary ( 1 LMW), compared to $31 \%$ (effective) that he would otherwise receive from depleting his savings under a market regime (see Table 4). This implies that his savings will cover 13 allowances/year worth $31 \%$ of 1 -LMW during 25 years. Hence, agent A receives a subsidy (measured in terms of replacement rate) of 69bps. Agent B receives a subsidy of $28 \mathrm{bps}$, agent C 27bps, and agent D 24bps. 
Table 4. Per-capita pension subsidy, base scenario (replacement rate, \%)

\begin{tabular}{llll}
\hline & & Replacement Rate & \\
\hline Agent type & Bid & Actual & Subsidy \\
\hline A (1 LMW) & 100.0 & 25.6 & 74 \\
B (2 LMW) & 64.5 & 30.1 & 34 \\
C (5 LMW) & 63.0 & 30.1 & 33 \\
D (10 LMW) & 60.5 & 30.1 & 30 \\
\hline
\end{tabular}

Note. Assuming each agent contributes for 25 years and enjoys pension for 30 years.

Once we plug these subsidies into the wage distribution, we obtain a pension subsidy NPV due to the transfer effect of $45.9 \%$ of GDP $(=24 \% 1 \mathrm{LMW}+7 \% 2 \mathrm{SML}+10 \% 5 \mathrm{SML}+5 \% 10 \mathrm{SML})$, see Figure 9 . To this, we must add the figure corresponding to contributions (41\% of GDP) in order to obtain the gross NPV of transfers, amounting to $87 \%$ of GDP.

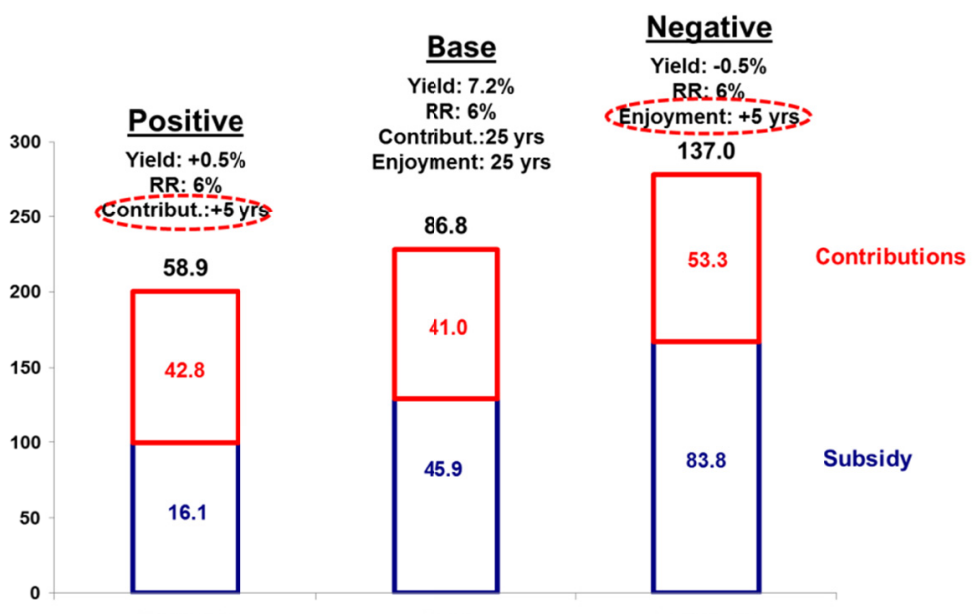

Figure 9. Gross pension NPV of RAIS-RPM transfers (\% GDP)

Consequently, by aggregating the gross NPV from transfers to our previous estimation of pension NPV of $141.3 \%$ of GDP (resulting from updated mortality tables), we reach a total gross pension NPV worth $228 \%$ of GDP, resulting from $129.5 \%$ subsidy plus $98.6 \%$ in contributions.

Under our optimistic scenario (real return of $7.7 \%$ and 30 year contributions), the total gross NPV would decrease to $200 \%$ of GDP (-28\% of GDP against base case). On the other hand, under the stress scenario $(6.7 \%$ real return and 30 year enjoyment), pension NPV would amount to $278 \%$ of GDP ( $+50 \%$ of GDP against the base case).

\subsection{Life Annuity Premium Estimation}

By using a cash-flow model, our estimations suggest that the premium on a life annuity that guarantees 1-LMW would be close to $\$ 146$ million (pesos of 2015), accounting for 20 years of enjoyment. Notice how the price for this premium will increase throughout the period of enjoyment, reaching a premium of $\$ 279$ million for the case in which enjoyment lasts 50 years. Therefore, by considering the distribution probability of enjoyment, we obtain a weighted average of 25 years, consistent with a premium worth $\$ 170$ million, see Table 5 .

Table 5. Per-capita pension subsidy, base scenario (replacement rate, \%)

\begin{tabular}{llllllll}
\hline & $\begin{array}{l}\text { Probability of } \\
\text { enjoyment }\end{array}$ & $50 \%$ & $30 \%$ & $10 \%$ & $7 \%$ & $\begin{array}{l}\text { Expected } \\
\text { Value }\end{array}$ \\
\hline & Years of enjoyment & 20 & 25 & 30 & 40 & 50 & 24.8 \\
\hline$(1)$ & Total savings & 31.9 & 31.9 & 31.9 & 31.9 & 31.9 & 31.9 \\
$(2)$ & Life annuity premium & 146.0 & 174.2 & 192.4 & 243.4 & 279.1 & 169.9 \\
$(3)=(2)-(1)$ & Shortfall & 114.1 & 142.3 & 160.5 & 211.5 & 247.2 & 138.0 \\
$(4)=(3) /(2)$ & Shortfall (\%) & $78 \%$ & $82 \%$ & $83 \%$ & $87 \%$ & $89 \%$ & $81 \%$ \\
\hline
\end{tabular}


Let us recall that an individual that contributes on 1 LMW would save close to $\$ 32$ million throughout his working lifespan (taking into account 25 years of contribution and a $7.2 \%$ real return rate on AFP's. Under current regulation, once this individual reaches the de-accumulation stage of his pension cycle, he must acquire a life annuity of at least $1 \mathrm{LMW}$, in order to guarantee a minimum pension, as given by the Constitutional mandate. Nevertheless, these results shows how this individual will withstand a shortfall worth $\$ 138$ million $(=\$ 170$ cost of premium - $\$ 32$ savings), equivalent to $81 \%$ of the total value of the premium.

For an individual that contributes on $2 \mathrm{LMW}$, his savings would amount to $\$ 64$ million by the end of his working life. Nevertheless, because the market can only fund a replacement rate between $45 \%-50 \%$ (not $100 \%$ or even the $65 \%$ set by Law 797 of 2003), this will determine the allowance (given by the annuity) the individual will obtain. Hence, considering that this allowance (indexed to inflation) cannot fall below the 1-LMW mark (inflation + labor productivity), we must consider a replacement rate of $85 \%(1.7 \mathrm{LMW})$, in order to secure that these conditions are met (pension must be worth at least 1 LMW during the entire life of the pension). With this in mind, each individual that contributes on $2 \mathrm{LMW}$, would face a shortfall worth $\$ 196$ million (= $\$ 260$ cost of premium - $\$ 64$ savings), equivalent to $75 \%$ of the total value of the premium, see Table 6 .

Table 6. Life annuity shortfall: 2-LMW contribution-1.7-LMW annuity (\$ million of 2015)

\begin{tabular}{llllllll}
\hline & Probability of enjoyment & $50 \%$ & $30 \%$ & $10 \%$ & $7 \%$ & $3 \%$ & $\begin{array}{l}\text { Expected } \\
\text { Value }\end{array}$ \\
\hline & Years of enjoyment & 20 & 25 & 30 & 40 & 50 & 24.8 \\
\hline$(1)$ & Total savings & 63.9 & 63.9 & 63.9 & 63.9 & 63.9 & 63.9 \\
$(2)$ & Life annuity premium & 227.8 & 266.8 & 292.2 & 354.9 & 395.5 & 259.9 \\
$(3)=(2)-(1)$ & Shortfall & 163.9 & 202.9 & 228.4 & 291.0 & 331.6 & 196.0 \\
$(4)=(3) /(2)$ & Shortfall (\%) & $72 \%$ & $76 \%$ & $78 \%$ & $82 \%$ & $84 \%$ & $75 \%$ \\
\hline
\end{tabular}

Clearly, our estimations give evidence of just how insufficient market parameters are in achieving a match between savings-premium, given current regulatory and demographic-legal conditions.

\section{Discussion}

Throughout this paper, we have analyzed the problems surrounding the Colombian pension system, both for the savings stage as well as the de-accumulation phase. Our findings encompass several fronts: i) the effect that a RAIS-RPM migration has on the estimated NPV for the pension system, including additional transfers that would result under a scenario of lower rates of return; and ii) by estimating the shortfall in the life annuities' market.

In what concerns the number of transfers from RAIS-RPM, the key element within our model lies from calculating semi-elasticities of current contributors against historical return rates for pension funds (AFPs). By estimating these parameters, we find a $+5.5 \%$ semi-elasticity between current RAIS contributors and the interest rate. This captures just how attractive it is for RAIS contributors to stay put in presence of higher market returns. On the other hand, we find a $-4.3 \%$ semi-elasticity for current RPM contributors. This result is consistent with the fact that there are greater incentives to migrate from RAIS to RPM when facing lower yields.

Our more estimations show that the pension NPV in Colombia is worth $141.3 \%$ of GDP, including adjustments for updated mortality tables. This gross NPV is made up of a subsidy component (83.6\% of GDP) and pension contributions (57.7\% of GDP). Nonetheless, in order for the government to cover the entire value of this gross NPV it must make use of the "uncovered PGN", because it has already consumed these contributions and has depleted RPM reserves since 2003. Furthermore, by aggregating this additional actuary cost of assuming larger RAIS-RPM transfers, the gross NPV rises to $228 \%$ of GDP (129.5\% from the subsidy component and $98.6 \%$ from contributions).

The pension system currently has a shortfall because of RPM migration, and this seriously affects the government's goal of reducing resources it sets apart for this objective, which are worth 4\% of GDP per year (close to $20 \%$ of the total budget).

Regarding the life annuities' market, we estimate value of the premium that an insurance company should charge on a life annuity by employing a cash-flow model. This estimation assumes that the key parameter is the amount of time of enjoyment of the annuity, considering potential beneficiaries as well as legal contingencies, considering the potential beneficiaries as well as legal contingencies.

Our estimations suggest that the premium on a life annuity that guarantees 1-LMW would be close to $\$ 146$ 
million (pesos of 2015), accounting for 20 years of enjoyment. Notice how the price for this premium will increase throughout the period of enjoyment, reaching a premium of $\$ 279$ million for the case in which enjoyment lasts 50 years. Therefore, by considering the distribution probability of enjoyment, we obtain a weighted average of 25 years, consistent with a premium worth $\$ 170$ million.

An individual that contributes on 1 LMW would save close to $\$ 32$ million throughout his working lifespan. Under current regulation, once this individual reaches the de-accumulation stage of his pension cycle, he must acquire a life annuity of at least $1 \mathrm{LMW}$, in order to guarantee a minimum pension, as given by the Constitutional mandate. Nevertheless, this individual will withstand a shortfall worth $\$ 138$ million $(=\$ 170$ cost of premium - $\$ 32$ savings), equivalent to $81 \%$ of the total value of the premium.

Clearly, our estimations give evidence of just how insufficient market parameters are in achieving a match between savings-premium, given current regulatory and demographic-legal conditions.

\section{Acknowledgments}

We greatfully thank FASECOLDA, the Colombian Insurance Association for supporting and funding this research. Any opinions, findings, and conclusions or recommendations expressed in this material are those of the authors and do not necessarily reflect those of FASECOLDA.

\section{References}

Anif. (2014). Mesadas Pensionales: ¿Cómo se afectan ante el monto ahorrado y las expectativas de vida? Comentario Económico del Día, 1.

Anif. (2014). Rentas vitalicias, retiros programados y aseguramiento. Comentario Económico del Día.

Anif. (2015). Déficits gemelos (externo y fiscal): Colombia vs. Estados Unidos. Informe Semanal No. 1285.

Anif. (2015). La reforma pensional que requiere Colombia: según la OECD. Comentario Económico del Día.

Anif. (2015). Recuperación Económica del mundo desarrollado: ¿Estancamiento Secular?. Comentario Económico del Día.

Anif. (2015). Rentas vitalicias y avances regulatorios. Comentario Económico del Día.

BIS. (2015). 85th Annual Report 2014-2015.

Center for Retirement Research. (2015). The funding of state and local pensions 2014-2018.

Clavijo, S., Vera, A., Malagón, D., Cabra, M., \& Vera N. (2013). El pasivo pensional en Colombia.

Clavijo, S., Vera, A., Ríos, A., \& Cuéllar, E. (2015). Costos no salariales en Colombia pos-Ley 1607 de 2012.

Superfinanciera. (2015). Presentación del Superintendente Financiero en el XXIV Convención Internacional de Seguros-Fasecolda, Cartagena.

\section{Copyrights}

Copyright for this article is retained by the author(s), with first publication rights granted to the journal.

This is an open-access article distributed under the terms and conditions of the Creative Commons Attribution license (http://creativecommons.org/licenses/by/4.0/). 